\title{
A Discussion on Sovereignty through World Society Concept
}

\author{
Dorina Ndoj, PhD. Cand. \\ European University of Tirana \\ dndoj1@uet.edu.al
}

\begin{abstract}
Nowdays sovereignty is a very intensely contested and controversial concept. The changes in international realm had an increasing impact upon the sovereignty of states. For more than two decades scholars have shown a growing interest to adress the emerging challenges to sovereignty concept. After all, the question about how could genuinely be possible to respond to challenges toward sovereignty is still vibrant. This paper aims to discuss the challenges to state sovereignty within the English School Theory, particularly focusing in the debate between society of states and world society concepts. The main English School paradigm argues that society of states is the most effective social construction that promotes friendly coexistence between political communities, and therefore its main principles are already worldwide accepted. New events on international realm, such as humanitarian interventions, globalization and the growth of the international institutions and organizations, have affect the activity of the society of states, which is mainly based on respect for the principle of sovereign equality. Contemporary theorists of the English School have responded to challenges to state-centrism through the concept of world society, which emphasizes the importance of individual and transnational actors in world politics. The thesis of this paper argues that there is an overlapping between society of states and world society caused by impact these changes has on the sovereignty of states. In order to address the challenges to sovereignty, the paper seeks to provide a new theoretical framework through world society concept to a better explaination the current international practice and the need to redefine sovereignty. World Society is very helpful concept in addressing the issues of human rights agenda, globalization, non-state actors and deterritorialization, which have undeniable impact on sovereignty of state.
\end{abstract}

Keywords: Sovereignty, Society of States, World Society, Globalization, Non-state Actors, Humanitarian Interventions.

\section{Introduction}

The principle of sovereignty has defined contemporary understanding of international relations. Since the Treaty of Westphalia it has remained the primary and overriding principle upon the organisation of the modern world has been based (Held \& McGrew, 2002:11). It recognizes states as key and autonomous actors of international relations. Sovereignty entitles states to independence in their internal affairs. It is because it has served as such a fundamental principle upon which the modern world is organised that recent questioning of state sovereignty, both as a legal principle and a normative claim, has caused such controversy within academic and foreign policy debates (Barkin \& Cronin, 1994: 107-130). In recent decades the concept has been changelled by various sources, so nowdays sovereignty is a higly contested and intensely controversial concept. The changes in international realm had an increasing impact upon the sovereignty of states. New events, such as humanitarian interventions, globalization and the growth of the international institutions and organizations, have challenged the traditional sovereingty. Sorensen suggests that "processes of globalisation making the world hang closer together; humanitarian intervention in weak states and attempts to create democracy and human rights on a global scale; new forms of intense co-operation in Europe and fresh attempts at regional integration elsewhere; the emergence of a large number of newly independent states; all these developments have helped spark new considerations about the possible implications for sovereignty" (Sorensen, 1999:590-604).

For more than two decades scholars have shown a growing interest to adress the emerging challenges to sovereignty concept. However the question about how could be possible to respond genuinely challenges to sovereignty is still vibrant. Furthermore, taking into account the new world dinamics it is undeniable not thinking about its re-conceptualization. Adressing the main challenges to sovereignty this paper aims to conceptualize an answer on how it could be possible to explain the changing nature of state sovereignty. This paper discusses the challenges to state sovereignty within the theoretical framework of the English School Theory, particularly focusing in the debate between society of states and world 
society concepts. It seeks to provide a better explain to the current international realm and the need to redefine the traditional notion of sovereignty by introducing a new concept such as world society.

\section{Discussing the Concept of Sovereignty within the English School Theory}

The English School Theory has developed the idea that society of states [international society] is the most effective social construction throughout human history that promotes coexistence between political communities based on mutual respect to sovereignty. The concept of society of states is the most developed concept within the English School Theory. "A society of states (or international society) exists when a group of states, conscious of certain common interests and common values, form a society in the sense that they conceive themselves to be bound by a common set of rules in their relations with one another, and share in the working of common institutions" (Bull, 2002). Society of states is an expression of socialization of states in the international arena. Socialization means the existence of certain principles and institutions, inter-subjectively accepted, that serve to conduct relations between states. It is the principle of sovereignty that leads to the socialization of states. States respect each other claims for independence that means a state or a governing body has the full right and power to govern itself without interference from outside sources or bodies. At the same time, they collaborate to build common institutions and share common interests. Bull argues that the society of states assumes relationship in conditions of anarchy, that means the lack of an supreme authority over the states. Relations in a society of states are organized on the basis of three principles: (a) sovereignty; (b) reciprocity; (c) the balance of power (Bull, 2002:52). Whilst the Society of States has gained a continuous growing interest, the concept of world society has been one of the most neglected concepts within the English School Theory. "World Society is most problematic features within the theoretical framework of the English School" (Little, 2000:411). According to Buzan "world society is understood in terms of invididuals, non-state actors or organizations and global population as the focus of global agreements and social identities" (2004:07). The idea of world society emphasizes the individual and transnational element.

The English School is often understood to be split into main wings: the pluralist and the solidarist. The pluralists argue that the essence of society of states is the preservation of international order, which itself maintain the sovereignty of member states. In general, pluralists oppose engagement in matters of human rights, interference in the internal state affairs and interest in individual and transnational terms considering as a violation of state sovereignty and therefore violation of the international order provided by the society of states. They support the activities of society of states focused on a minimal set of issues, which only guarantees the functional aspect of the society of states. It is all about the principles of sovereignty and non-interference, which makes possible the existence of international order. The solidarists claims that society of states should do more to promote human rights. According to them the international community is responsible to intervene when states fail to fulfill their responsibilities in the preservation of their citizens human rights. In solidarist perspective society of states's engagement should be expanded in a wider number of norms, rules and institutions, which reinforces international order and their commitment to promote and protect human rights.

New events, such as humanitarian interventions, globalization and the growth of the international institutions and organizations, have challenged the traditional sovereingty and had an increasing impact upon the state international engagement. The debate between pluralists and solidarist represents the convenient theoretical framework to incorporate the relationship between international society and world society and thus the issues challenging the concept of sovereingty. The society of states is experiencing a growing solidarity between states, not only in areas where states have traditionally cooperated, but also about issues that are regarded to undermine traditional sovereignty. The focus on individual unit through an intensive discourse on human rights and transnational agents provides evidence of a de facto world society. Thus world society should not be seen as undermining the existence of the society of states, cause states continue to exist and to enjoy the legitimate right to govern, but the society of states already moved towards a more solidarist side, where the focus of international society is not only an orderly coexistence and competition, but also collaboration on a scale of norms, rules and institutions shared between states. As researcher Thomas Hall presentes "Sovereignty should be reinterpreted as being conditional upon states acting responsibly to ensure the human rights and well-being of their citizens. Furthermore, given that in reality, decisions are made at levels above and below the state, sovereignty, and the legitimate right to rule should be dispersed to those levels" (Thomas, 2004:02). In order to explain the need for sovereignty reconceptualization this paper analyzes some of the issues that challenged the concept through lens of world society. The 
concept of world society provides arguments to support the thesis that society of states is moving towards a world society, where the latter does not threaten the first, but expands the scope of its activity. This means that state unit is still existent, but sovereignty definition has undergone changes. To elaborate these arguments the following parts cover the issues of humanitarian intervention and human rights, as well as economic relations and virtual territoriality.

\section{Human Rights and Humanitarian Interventions}

The issue of humanitarian intervention addresses one of the most widely examined phenomena under the umbrella of the concept of world society, focusing on the human rights pressure on changing the principle of sovereignty. In early 1990s through so-called humanitarian intervention the society of states used military force on a number of occasions to stop systematic and widespread human rights violation. Humanitarian intervention means the use of force by a state, group of states or an international organization with the specific aim to prevent or reduce the massive suffering and death of human beings (Evans \& Newnham, 1998:231). After the Cold War, the issue of humanitarian interventions has become part of the discourse and the international agenda. Humanitarian interventions have raised many discussions and doubts about their legitimacy. Despite the success or failure of these interventions, they have caused debate and contradictory attitudes towards them. The dominant discourse was that interventions aimed to protect human rights have violated the sovereignty of states. Thus humanitarian interventions are considered as an attempt to disregard the principle of sovereignty. These issues have been addressed focusing on the debate between pluralists and solidarists within the English School Theory. The two approaches offer different explanations. Pluralist approach opposes the practice of humanitarian intervention because it regards as a violation of state sovereignty where intervene had ocurred and as well as a violation of the international order of society of states. Interventions practice goes beyond the principles on which is based society of states. According to them states agree to cooperate only on a minimum of purposes, mainly mutual recognition of sovereignty and the principle of non-interference in the internal affairs of a state. The core of the society of states according pluralist approach is the preservation of international order, which itself provides the sovereignty of society of states members. Consequently opportunities for joint actions among states in matters of human rights are minimal. Sovereingty is refered in minimal terms, only as sovereignty over a particular territory. Pluralists concern that states in the absence of an international consensus on the governing rules of humanitarian intervention practice, will act based on their morality thus weakening the international order built on the basis of the principles of sovereignty, non-interference and restriction of force (Bull, 1984:193). Jackson stressing the importance of the state in international society, reinforces the idea that the weakening of the principle of non-intervention to achieve goals such as the protection and promotion of human rights risks conflicting states with each other, because such purposes are unacceptable and not fully understood (Jackson, 2000:24993).

Whilst solidarist approach provides arguments in support of interventions for humanitarian purposes. The issue of humanitarian intervention arises when a government has directed state machinery against its people, or when the state has collapsed due the lack of law (Wheeler, 2000:27). According to this perspective, society of states should engage in matters of justice, such as intervening to protect human rights when a state fails to meet responsibilities towards its citizens. When a state systematically and massively violates human rights it is a duty of the international community to undertake humanitarian intervention (Vincent and Watson, 1993:126). Solidarist argue that this is the only way to maintain international order. According to solidarist branch, when it comes to the principle of sovereignty, it should be conceived in minimal and maximal terms. In minimal terms sovereignty means ruling over the territory, where states should respect the territorial boundaries of each other. Unlike pluralists, solidarists emphasize that society of states consists on states and sovereigns (nations). Therefore it is important to consider the concept of sovereignty in maximal terms, which means the sovereignty of the people. Sovereignty means primary responsibility regarding the preservation of lives of people living within the state. Solidarists have developed a human rights agenda. The committment of society of states to protection and promotion of human rights makes possible the development of world society, since its focus expands on human rights and solidarity dimension that should exist between countries refering the individual level, which in this context means the rights of citizens within a state. Focusing on individual level it is possible to move from society of states to world society.

\section{Economic Relations: Interdependence, Globalization and Deterritorialization.}


This part of paper addresses interdependence and globalization processes, as challenges to territorial sovereignty and as an excellent opportunity to explore the potentiality of the world society. The idea of world society is widely used to bring non-state actors in the social structure of the international system (Buzan, 2004: 63). The early English School thinkers have not shown interest about economic aspect refering to the in the activity of a country. The English School, especially in its classical form, is obviously a state-centric approach (centered in the state) and has been highly criticized for failing to take in account the implications of international economy (Williams, 2001). In his work Bull has dedicated little space to factors and forces economic, and has shown little interest in formal international institutions in this regard. In the view of Andrew Hurrell, Bull has minimized the dynamic forces in global politics and failed to recognize the extention to which the system was shifting towards a post-vestfalian reality (Hurrell, 2002:xv). For many scholars Bull's focus in the society of states is totally inadequate and obsolete due to factors such as the impact of economic globalization and political democratization, the growing importance of transnational civil society, the increase in density, scope and scale of international institutions, as well as the multiple problems of disintegration and ethnic conflicts in some countries (Hurrell, 2002:xv). It is incomprehensible the lack of attention to economic dimension within the English School, cause it plays an important role in discussions on international society and world society (Buzan, 2004:19). The idea of world society is the key to connect the theory of English School and debates about globalization (Buzan, 2004; Weller 2000). Globalization is defined as deterritorialization of social life, which has created new actors and networks alongside existing ones, where the territoriality and supraterritoriality coexist in a complex interaction (Scholte, 2000:8-9, 59-61).

Interdependence and international economic cooperation are the main features of modern international relations. The concepts of interdependence and globalization are often used interchangeably. Most studies refere to globalization as the intensification of economic, political, social and cultural relations across borders (Holm \& Sorensen, 1995). Virtually every country in the world is now part of international agreements, which in some way affect their formal authority to make and implement free economic policies from external interference and involvement (Petrie, 2009:11). Such agreements include a wide range of areas, the market, monetary cooperation, investment, regulatory norms, etc. In the framework of the economic cooperation and integration between countries, the biggest concern is about the impact of integration on the sovereignty of states. Despite its central role in international relations, the state is facing challenges from globalization processes based on transnational movements. In external dimension, the state was hit by globalization, increased integration in terms of political, economic, and cultural communication, a process that is increasingly undermining the traditional sovereignty of states (Mingst, 2004:129). In political terms, the state is facing diverse global threats from environmental degradation and disease to security threats, which tgovernment can inevitably not manage alone. These issues require unprecedent political cooperation among states since in most cases national authorities have not the capacity to address them alone. Such cooperative actions increasingly force states to make compromises that affect their sovereignty. In economic terms, countries and financial markets are closely related to each other. For example the global financial crisis of 2010 had long-term implications that went beyond the realm of global finance by influencing social and political dynamics around the world. International financial organizations, multinational corporations and the internationalization of production and consumption are making it even more difficult for states to regulate their economic policies (Mingst, 2004: 130). Also in cultural terms, new technologies are shrinking state control over the information and thus giving rise to the creation of a global civil society or the "global village"in McLluhan term.

In a structural perspective and in terms of globalization, identity and interests of states may be expressed by means of transnational cooperation rather than territorial defense (Streeck, 1996:299). The emerge of a transnational civil society has become inevitably by globalization processes. Only after the Cold War period, the terms of civil society and global transnacional civil society have been used in the academic literature of international politics. Mary Kaldor (2003) argues that meaning of these terms is subject to widely different interpretations (Kaldor, 2003). However, they are referred to as non-governmental and non-profit voluntary collective action around common interests, values and goals (Scholte, 1999:23). While global civil society includes activities that expand and have effect throughout the world (Keane, 2003:8), the concept of transnational civil society refers to collective actions of non-governmental and non-profit organizations that overcome national boundaries, but not necessarily have global impact. The main actors of non-governmental transnational civil society, which are not profitable, not serve as instruments of government (Salamon \& Anheier, 1997). One of the important factors that influence the creation of transnational civil society is the development of the global economy. The existence of transnational civil society emphasizes the transnational element that characterize the world society concept. 
Much has been written about the challenges that globalization poses upon sovereignty, but the fact that economic integration weakens the sovereignty of states is not at all something new (Hoffman, 1997:54). However, there is a need to explain the interconnection between globalization and sovereignty. First, neither globalization and nor interdependence do not challenge the formal legal sovereignty of states, cause only other states can do that (Reinicke \& Witte, 1999). Globalization challenges operational sovereignty of the government, which has to do with the ability to exercise sovereignty public policy making. Second, according to John Hoffman, states make "double life" on sovereignty which has two dimensions, one internal and one external (Hoffman, 1997:54). Internal dimension concerns the relationship between the state and civil society, where the state has the monopoly of legitimate power in a various areas, including the economy. Economic aspect of internal sovereignty is exercised by government when it collects taxes and regulates the activity of the private sector. The external dimension of sovereignty refers to the relationship of states in the international system. States exercise their external sovereignty in economic terms, for example when setting fees or change exchange rates. So economic interdependence is challenging external dimension of sovereignty. Responding to this challenge governments largely follow the principles of economic liberalism, thus reducing their external sovereignty on economic approval or determination of the international regulatory norms. Such a reduction is structured around a set of international norms and standards rooted in international mechanisms such GATT, IMF, WTO, etc., (Krasner, 1983). The concept of external sovereignty loses much of its significance when analyzing the impact of globalization (Reinicke \& Witte, 1999). Global corporations pose a challenge to the internal sovereignty by modifing spatial relationship between public and private sectors. Organizational logic of globalization promotes corporations that seek integration of the national markets into global one. International markets are not dependent of the presence of boundaries. Although governments continue to be limited by the territoriality, they can not project their power over the total area where production and consumption organize themselves (Reinicke \& Witte, 1999).

Any discussion on society of states that goes beyond state should take into account the transnational activities of individuals, social groups, firms or corporations. These social actors have significant effects on the movement of material resources and ideas around the world, and thus can not be completely ignored in international relations. They coexist and interact with states. In this sense, understanding of world politics depends on understanding the different types of social actors who operate different transnational relationships that may exist between them and states, and on the ways they influence states. Discussing the challenges of globalization process, many scholars have focused on the growing importance of non-state actors and international organizations in the so-called new structure of global governance, thus breaking the tradition of the state monopoly on legal grounds (Mathieus, 2011). Meanwhile, others argue that the new world order does not imply a change from state to non-state actors. They argue that states exist though being demolished in their functional and coperating parts with corresponding structures in other countries, thus creating a dense network that constitute a new intergovernmental rule (transgovernmental) (Slaughter, 1997:197). Non-state actors play a transformative role in changing interests, identities and thus incentives state actors in making part of the global legal obligations. As Wendt says when states interact with each other happens more than realists and rationalists accept (Wendt, 1992).

The proponents of "new sovereignty" (re-conceptualization of sovereignty) claim that society is being meaningfuly transformed thus paving way for a re-conceptualization of the principle of sovereignty. Democratic governance coerce social response to growing demands. Once states were relatively autarkic, but nowadays interdependence and globalization make impossible for states to act alone ensuring desirable policy results to their citizens. Traditional sovereignty is challenged due major changes in the international system as well as the demands and needs of citizens within states. The development of the principle of sovereignty has occurred over the past four centuries throughout ongoing controversy about its meaning. What has remained constant in the understanding of sovereignty is that it has been connected and constantly interpreted as final and absolute political authority within a defined territory (Hinsley, 1986; Philpott, Ruggie, 1993). Philpott claims that in more specific definition sovereignty has the meaning of "supreme authority within a territory" (Philpott, 1997). This understanding of sovereignty dates back to Bodin discussions in 1576, where he defined sovereignty as "higher, absolute and uninterrupted power upon citizens" (Bodin, 1962:86). Also, both Hobbes and Hegel defined sovereignty as a supreme and absolute power claiming that sovereignty rules free from any restrictions (Lapidoth, 1992:326). By the Treaty of Westphalia in 1648, the concept of sovereignty was not related to the territorial state (Jackson, 1999:438-441). Philpott claims that this treaty brought not only the beginning of the modern state system, but also a revolution against sovereignty (Philpott, 1993: 579-582). Whilts today is increasingly suggested the movement to a post-sovereign world where absolute and legitimate state authority is not territorially defined (Thomas, 2004:04). The tension between pluralists and solidarists is rooted in someways in the meaning of territorial sovereignty of international society. In the pluralist perspective, territorial sovereignty of society of states has a significant importance. Despite 
discourse on deterritorialization the boundaries separating the states in the international system determinate power and sovereignty in the modern world (Newman \& Paasi, 1998). Under Vestfalian system of states territorial boundaries are determinants to provide the maintainance of interstate order through mutual recognition of territorial integrity and territorial sovereignty. In recent decades a "supraterritorial" global society vision created partly by the economic, political, financial and social dynamics of globalization and partly by international society itself, provide an agenda to include its potential expansion beyond the society of states. Due the challenges to territorial sovereignty posed by globalization processes have been an increasing discourse on global society (Newman, 2005). The impact of globalization on resilience, flexibility and permeability of borders is significant, as it allows greater movement of people, goods, information and cultural exchanges (Shapiro \& Alker, 1996). However the impact of these changes remains highly differentiated, it has contributed in better understanding of the concept of world society. World society is aimed at capturing the interpaly amongst states, non-state actors and individuals, and in the sense that all actors in the system are aware of their interconnection and some shared values (Dunne, 2001).

\section{Conclusions}

This paper aimed to provide a better explaination to the current international realm and the need to redefine the traditional notion of sovereignty by introducing a new concept such as world society. The English School Theory is ideally suited to address the discussions on challenges to traditional sovereignty concept through world society concept. Given the fact that sovereignty is the essential principle of international society the debate among pluralists and solidarist within the English School Theory represents the convenient theoretical framework to incorporate the relationship between international society and world society and thus explaining the changing nature of state sovereignty. The changes in international realm had an increasing impact upon the sovereignty of states. Drawing evidence on humanitarian interventions, globalization and the growth of the international institutions and organizations, traditional sovereignty is challenged due major changes in the international system, as well as the increasing demands and needs of citizens within states. The thesis of this paper claims that world society concept provides explaination to the challenged external dimension of sovereignty. The society of states is facing a increasing solidarity among states, not only in areas where states have traditionally cooperated, but also about issues that are regarded to undermine their sovereignty. The focus on individual unit through an intensive discourse on human rights and transnational agents provides evidence of a de facto world society. Thus world society should not be seen as undermining the existence of the society of states, cause states continue to exist and to enjoy the legitimate right to govern, but the society of states already moved towards a more solidarist side, where the focus of international society is not only an orderly coexistence and competition, but also collaboration on a scale of norms, rules and institutions shared between states. This paper examined some of the issues that have challenged the sovereignty concept, such humanitarian interventions, globalization, economic interdependence and virtual territoriality, cause they are challenging external dimension of sovereignty.

\section{References}

[1] Buzan, B. (2004). From International to World Society? English School Theory and the Social Structure of Globalisation. Cambridge: Cambridge University Press.

[2] Bull, H. (2002). The Anarchical Society: A Study of Order in World Politcs. London: Palgrave Macmillan.

[3] Bull, H. (1984). Interventions in world Politics. Oxford: Clarendon Press.

[4] Barkin, J., \& Cronin, B. (1994). The State and the Nation: Changing Norms and the Rules of Sovereignty in International Relations. International Organisation, Vol. 48(1), 107-130.

[5] Dunne, T. (2001). New Thinking on International Society. British Journal of Politics and International Relations, Vol. 3, No. 2, 223-244.

[6] Evans, G., \& Newnham, J. (1998). Dictionary of International Relations. London: Penguin Reference.

[7] Held, D., \& McGrew, A. (2002), Globalisation/ Anti-Globalisation. Cambridge: Polity Press.

[8] Hoffman, J. (1997). Blind Alleys. Can We Define Sovereignty? Politics, Vol. 17, No. 1, 53-53.

[9] Hinsley, F. H. (1967). Power and the Pursuit of Peace: Theory and Practice in the History of Relations Between States. Cambridge: Cambridge University Press. 
[10] Holm, H., \& Sorensen, G. (1995). Whose World Order? Uneven Globalization and the End of the Cold War. Boulder: Westview.

[11] Jackson, R. H. (2000). The Global Covenant: Human Conduct in World of States. Oxford: Oxford University Press.

[12] Jackson, R. (1999). Sovereignty in World Politics: A Glance at the Conceptual and Historical Landscape. Political Studies, Vol. 47, 431-456.

[13] Keane, J. (2003). Global Civil Society? Cambridge: Cambridge University Press.

[14] Kaldor, M. (2003). Global Civil Society: An Answer to War. Cambridge: Polity Press.

[15] Krasner, S. D. (2004). Sharing sovereignty: new institutions for collapsed and failing states. International Security, 29(2), 85-120.

[16] Little, R. (2000). The English School's Contribution to the Study of International Relations. European Journal of International Relations, 6(3), 395-422.

[17] Mingst, K. (2008). Essentials of International Relations. New York: W. W. Norton \& Company.

[18] McGrew, A. (2004). Cosmopolitanism and Global Justice. The International Studies Association of Ritsumeikan University, Vol.3, 1-17. Retrieved from: http://www.ritsumei.ac.jp/acd/cg/ir/college/bulletin/e-vol.3/mcgrew.pdf (January 2015).

[19] Newman, D. (2005). World Society, Globalization and a Borderless World The Contemporary Significance of Borders and Territory. Department of Politics and Government, Ben Gurion University.

[20] Philpott, D. (2001). Revolutions in Sovereignty: How Ideas Shaped Modern International Relations. Princeton:Princeton University Press.

[21] Petrie, M. C. (2009). Jurisdictional Integration: How Economic Globalisation is Changing State Sovereignty. Doctoral Dissertation, Victoria University of Wellington.

[22] Reinicke, W. H., \& Witte, J. M. (1999). Interdependence, Globalization, and Sovereignty:The Role of NonBinding International Legal Accords. Oxford: Oxford University Press.

[23] Sorensen, G. (1999). Sovereignty: Change and Continuity in a Fundamental Institution. Political Studies, Vol. $47,590-604$.

[24] Scholte, J. A. (1999). Global Civil Society: Changing the World? Coventry: Centre for the Study of Globalization and Regionalization (CSGR), University of Warwick.

[25] Salamon, L. M., \& Anheier, H. K. (1997). Defining the Nonprofit Sector: A Cross-National Analysis. Manchester: Manchester University Press.

[26] Streeck, W. (1996). Public Power Beyond the Nation-State: The Case of the European Community. In Boyer, R., \& Drache, D. (Eds.). States against Markets in The Limits of Globalization. London: Routledge.

[27] Thomas, H. (2004). Cosmopolitan Sovereignty. Refereed paper presented to the Australasian Political Studies Association Conference University of Adelaide. Retrieved from:https://www.adelaide.edu.au/apsa/docs_papers/Others/Thomas.pdf (January 2015).

[28] Vincent, R. J., \& Watson, P. (1993). Beyond the non-intervention: Political Theory, International relations and the Ethics of Intervention. London: Macmillan.

[29] Williams, J. (2009). Pluralism and World Society: Accepting the Normative Challenge. School of Government and International Affairs, Durham University.

[30] Wheeler, N. J. (2000). Saving Strangers: Humanitarian Intervention in International Society. Oxford: Oxford University. 
